\title{
Serum levels of bone formation and resorption markers in relation to vitamin D status in professional gymnastics and physically active men during upper and lower body high-intensity exercise
}

\section{Jan Mieszkowski}

Akademia Wychowania Fizycznego i Sportu im Jedrzeja Sniadeckiego w Gdansku

Andrzej Kochanowicz

Akademia Wychowania Fizycznego i Sportu im Jedrzeja Sniadeckiego w Gdansku

Elżbieta Piskorska

Uniwersytet Kazimierza Wielkiego

Bartłomiej Niespodziński

Uniwersytet Kazimierza Wielkiego

Joanna Siódmiak

Uniwersytet Kazimierza Wielkiego

Krzysztof Buśko

Uniwersytet Kazimierza Wielkiego

Dorota Olszewska-Stonina

Uniwersytet Kazimierza Wielkiego

Jedrzej Antosiewicz ( $\square$ jant@gumed.edu.pl )

Medical University of Gdansk https://orcid.org/0000-0002-7871-6469

Research article

Keywords: PINP, CTX, gymnast, vitamin D

Posted Date: January 14th, 2021

DOI: https://doi.org/10.21203/rs.3.rs-50555/v2

License: (c) (i) This work is licensed under a Creative Commons Attribution 4.0 International License.

Read Full License

Version of Record: A version of this preprint was published at Journal of the International Society of Sports Nutrition on April 13th, 2021. See the published version at https://doi.org/10.1186/s12970-021- 
00430-8.

Page $2 / 20$ 


\section{Abstract}

Purpose/Introduction: To compare serum levels of bone turnover markers in athletes and non-athletes, and to evaluate the relationship between serum levels of vitamin D metabolites and exercise-induced changes in biomarker levels.

Methods: Sixteen elite male artistic gymnasts (EG; $21.4 \pm 0.8$ years-old) and 16 physically active men (the control group, PAM; $20.9 \pm 1.2$ years-old) performed lower and upper body 30-s Wingate anaerobic tests (LBWT and UBWT, respectively). For biomarker analysis, blood samples were collected before, and 5 and $30 \mathrm{~min}$ after exercise. Samples for vitamin D levels were collected before exercise. $\mathrm{N}$-terminal propeptide of type I collagen (PINP) was analysed as a marker of bone formation. C-terminal telopeptide of type I collagen (CTX) was analysed as a marker of bone resorption.

Results: UBWT fitness readings were better in the EG group than in the PAM group, with no difference in LBWT readings between the groups. UBWT mean power was $8.8 \%$ higher in subjects with $25(\mathrm{OH}) \mathrm{D}_{3}$ levels over $22.50 \mathrm{ng} / \mathrm{ml}$ and in those with $24,25(\mathrm{OH})_{2} \mathrm{D}_{3}$ levels over $1.27 \mathrm{ng} / \mathrm{ml}$. Serum CTX levels increased after both tests in the PAM group, with no change in the EG group. PINP levels did not change in either group; however, in PAM subjects with $25(\mathrm{OH}) \mathrm{D}_{3}$ levels above the median, they were higher than those in EG subjects.

Conclusion: Vitamin D metabolites affect the anaerobic performance and bone turnover markers at rest and after exercise. Further, adaptation to physical activity modulates the effect of anaerobic exercise on bone metabolism markers.

\section{Introduction}

Physical exercise affects the osseous tissue by causing dynamic changes in the local mechanical conditions, thus stimulating the resident osteocytes through fluid shifts in the canalicular network [1]. Whenever a mechanical load is imposed on the osseous tissue, it induces an osteogenic response and activation of specific bone cell types (osteoclasts, osteoblasts, and osteocytes) [2]. Osteocytes effectively identify the mechanical signals, since they are located in small cavities, the lacunas, in the mineralized bone matrix. While transmitting signals to other cells, osteocytes initiate the bone tissue rebuilding process [3, [4]. The mechanism by which mechanical energy is transformed into electrical stimuli, with subsequent biochemical responses, is called mechanotransduction and plays a key role in skeletal adaptation to the actual mechanical load [5].

Typically, the human bone mass is evaluated using X-rays and by densitometry. These two methods are well known and widely used. However, they do not reflect the status of the bone as a living tissue, as they only analyse bone microarchitecture and location. Further, many scenarios call for the analysis of substances produced during bone activity and bone metabolism. Indeed, products of bone cell activity serve as markers of bone formation, and their levels reflect the bone cell function under specific circumstances, e.g. physical activity [6]. 
Analysis of specific biochemical markers of bone turnover may shed light on the effects of physical activity on bone metabolism during high-intensity exercise and as an effect of long-term adaptation. Further, analysis of the bone metabolic markers may inform the diagnosis and monitoring of bone metabolic disorders related to skeletal overload during highly intensive physical activity [6]. One field in which such knowledge may be applied is gymnastics, as a sport in which the bone is under pressure from specific activities, such as jumps, upheavals, and other weight-bearing activities. However, the mechanisms whereby physical exercise affects bone metabolism have not yet been fully elucidated.

Many markers of bone formation and resorption have been established. The former include bone-specific alkaline phosphatase, osteocalcin, and the $\mathrm{C}$ - and $\mathrm{N}$-terminal propeptides of type I collagen (PICP and PINP, respectively). The latter include pyridinoline, deoxypyridinoline, and $\mathrm{N}$ - and $\mathrm{C}$-terminal telopeptides of type I collagen (NTX and CTX, respectively) [7]. PINP and CTX have gained particular attention. PINP is released into the intracellular space and its levels reflect the number of newly formed collagen molecules [8]. On the other hand, CTX serum levels are used to determine the rate of bone turnover. CTX levels are increased during osteoporosis, osteopenia, and Paget's disease [1, [9]. Conversely, it has been reported that lower levels of PINP are associated with hyperinsulinemia and hyperglycemia in healthy individuals [10]. Beside CTX has been reported to be a predictive factor of an increased carotid intima-media thickness in the elderly population [11]. Thus, understanding the effects of exercise on these markers can help to get inside on the mechanism of adaptation process and pro-healthy effects.

Several reports on the effect of single exercise and regular training on bone marker levels have been published; however, the data are not consistent. Without a doubt, exercise intensity and its nature, in conjunction with dietary factors, determine the bone marker response. For example, a calcium-rich meal pre-exercise reduces the levels of bone resorption markers induced by cycling [12]. Of note, many indoor athletes who practice certain sports are vitamin D-deficient [13]. Vitamin D plays an important role in bone metabolism. It also influences skeletal muscle strength, reduces muscle atrophy and parathyroid hormone concentration, and exerts many other effects $[14,[15,[16]$. Despite of these positive effects, to the best of our knowledge, the acute effect of exercise on bone formation and resorption markers in relation to vitamin $D$ status had not yet been assessed. Hence, the primary aim of the current study was to evaluate the effects of vitamin D status on changes in the serum PINP and CTX levels induced by Wingate anaerobic test (WAnT) in highly trained athletes and untrained young men.

\section{Method}

\section{Ethics statement}

Experimental procedures and study design were approved by the Bioethics Committee for Clinical Research at the Regional Medical Chamber in Gdansk, Poland. The study was conducted according to the 1964 Declaration of Helsinki and its later amendments. Each participant gave a written consent to participate in the study, and was informed about the purpose and test procedures, and the possibility of withdrawal of consent at any time and for any reason. 


\section{Participants}

A group of 16 elite male artistic gymnasts $(E G)$ aged $20.6 \pm 3.3$ years-old and 16 physically active men (PAM) aged $19.9 \pm 1.0$ years-old participated in the study. Descriptive physical characteristics are shown in Table 1.

Table 1. Physical characteristics of the study participants $(n=32)$

\begin{tabular}{|l|l|l|l|l|l|}
\hline \multirow{2}{*}{ Variable } & \multicolumn{2}{|l|}{ EG $(\mathrm{n}=16)$} & \multicolumn{2}{l|}{ PAM $(\mathrm{n}=16)$} & \multirow{2}{*}{ Effect size $\left(\eta^{2}\right)$} \\
\cline { 2 - 5 } & Mean \pm SD & $(95 \%$ CI $)$ & Mean \pm SD & $(95 \%$ CI $)$ & \\
\hline Body height $(\mathrm{cm})$ & $171.31 \pm 3.92 *$ & $(169.21-173.40)$ & $178.47 \pm 5.08$ & $(175.85-181.08)$ & 0.39 \\
\hline Body mass $(\mathrm{kg})$ & $69.30 \pm 6.79$ & $(65.68-72.92)$ & $72.99 \pm 10.07$ & $(67.81-78.17)$ & 0.04 \\
\hline BMI $\left(\mathrm{kg} \cdot \mathrm{m}^{-2}\right)$ & $23.56 \pm 1.54$ & $(22.74-24.39)$ & $22.29 \pm 3.11$ & $(21.32-24.52)$ & 0.01 \\
\hline Per cent body fat $(\%)$ & $6.78 \pm 3.10^{*}$ & $(5.12-8.44)$ & $11.16 \pm 4.83$ & $(8.69--3.62)$ & 0.21 \\
\hline
\end{tabular}

Note: BMI, body mass index; EG, elite gymnast; PAM, physically active man.

*Significant difference between gymnasts and controls at $\mathrm{p}<0.01$.

All gymnasts have been training regularly since 6-8 years old. (five times per week, 2-3h per unit). At the time of the research, all gymnasts were in the highest form of preparation for participation in national and international competitions (senior level). During one week of training, the athletes completed from 9 to 10 training units lasting no more than 200 minutes (per unit). The four training session included mainly high intensity anaerobic performance. The effective duration of each session ranged from 12 to 18 minutes during which it was performed; jumping; squat jump; drop jump; sprint with the load; pushups; pull up exercises including abdominal muscles, core, and arm strength training; back; and other specialized exercises using various training simulators. The remaining five training sessions included technical skills (floor exercises, pommel horse, rings, vault, parallel bars, and horizontal bar). The effective duration of a single session ranged from 40-50 minutes during which 210 to 270 gymnastic exercises were performed on selected aparatus, including 10 to 20 vault jumps. Elements from the higher difficulty groups (C, D and E) according to the Code of Points 2017-2020 International Gymnastics Federation classification constituted from 30 to $40 \%$ of all performed exercises. . PAM population declared regular participation in recreational sports, such as running, swimming, and team sports (on average, 2-3 times per week, 45-60 minunit). PAM were untrained in professional gymnastics and served as a control group for long-term gymnastic training.

All of the participants had a normal health status 3 months prior to the study, specifically, no injuries to the bone or the muscle tissue; no intake of drugs during the study; negative medical history regarding disorders of the cardiovascular system, autonomic nervous system, mental disorders, craniocerebral trauma, and other diseases that might directly affect the obtained results. The participants were informed of the nature and possible inconveniences associated with the experiment and the fact that they can opt out at any stage of the study.

\section{Experimental overview}


The study consisted of two parts:

(1) measurement of the anaerobic components of fitness using WAnT, i.e. upper and lower body highintensity exercises;

(2) assessment of the serum levels of PINP (bone formation marker) and CTX (bone resorption marker), and vitamin $D$ metabolites in serum samples collected in part (1).

The participants were instructed to avoid caffeine, alcohol, and any substances that could have influenced their physical performance 1 month before the experiment. All participants attended a 1-h familiarization session

1 week prior to the experiment, to ensure that they were familiar with the testing equipment and procedures. Further, $48 \mathrm{~h}$ prior to testing, the participants were asked to refrain from exhaustive exercise, to maintain their normal dietary habits, and to come to the laboratory in a euhydrated state.

All participants performed the lower and upper body WAnT (LBWT and UBWT, respectively). The actual measurements began with LBWT. Before the test, venous blood for serum isolation was taken at rest, and 5 and 30 min after test completion. One week later, the participants completed the UBWT. Blood samples were collected at rest before and after the test, as for the LBWT.

\section{Measurements of the anaerobic components of fitness: LBWT and UBWT}

LBWT was conducted using a cycle ergometer (Monark 894E, Peak Bike from Sweden) with MCE 5.1 software package („JBA” Zb. Staniak, Poland). For each participant, the saddle height was adjusted so that the knee remained slightly flexed after the completion of the downward stroke (with the final knee angle of approximately $170-175^{\circ}$ ). Toe clips were used to ensure that the participant's feet were held firmly in place and in contact with the pedals. Before any experimental testing, each individual completed a standardised warm-up on the cycle ergometer ( $5 \mathrm{~min}$ at $60 \mathrm{rpm}, 1 \mathrm{~W} / \mathrm{kg}$ ).Each participant was required to pedal with maximum effort for a period of $30 \mathrm{~s}$ against a fixed resistive load of $75 \mathrm{~g} / \mathrm{kg}$ of total body mass as recommended by Bar-Or 0 [17].

UBWT was conducted using a hand cycle ergometer (Monark 891E). Participants sat in a chair affixed to the ground, and were advised to keep their feet flat on the ground and remain seated throughout the WAnT. The seat height and backrest were adjusted so that, with the crank position on the opposite side to the body and the hand grasping the handles, the elbow joint was almost fully extended $\left(140-155^{\circ}\right)$ and the shoulders were in line with the centre of the ergometer's shaft. A standard resistive load equivalent to $50 \mathrm{~g} / \mathrm{kg}$ of total body mass was used for each participant. Before the test, the participants completed a warm-up that involved 5 min of arm cranking at a power output of $1 \mathrm{~W} / \mathrm{kg}$ and a crank rate of $60 \mathrm{rev} / \mathrm{min}$.

For both WAnTs, each participant was instructed to cycle as fast as possible and was given a 3-s countdown before the set resistance was applied. Verbal encouragement was given to all participants to maintain their highest possible activity throughout the tests. Both cycle ergometers were connected to a PC to allow data capture via the MCE 5.1 software. The following WAnT variables were measured: peak 
power $(\mathrm{W})$ and relative peak power $(\mathrm{W} / \mathrm{kg})$, calculated as the single highest point of power output (recorded at 0.2-s intervals); mean power (W) and relative mean power (W/kg), calculated as the average power output during the 30 -s test.

\section{Sample collection and methodology}

The blood for biochemical analyses was collected three times on the day of each test (immediately before, and 5 and 30 min after WAnT completion) into serum separation tubes (Becton Dickinson, Oxford, UK). The blood was collected at rest, fasting, and in the morning (07:00-08:00). The tubes were centrifuged at $2000^{\prime} \mathrm{g}$ for $10 \mathrm{~min}$ at $4^{\circ} \mathrm{C}$ and stored at $-80^{\circ} \mathrm{C}$ until analysis.

\section{Serum CTX assay}

Serum CTX levels were determined by using IDS-iSYS CTX (CrossLaps ${ }^{\circledR}$ ) (Immunodiagnostic Systems, Tyne and Wear, UK), a chemiluminescence immunoassay, and iSYS analyser, according to the manufacturer's protocol. Before the analysis, the serum aliquots were kept frozen at $-80^{\circ} \mathrm{C}$, and had only be thawed once, i.e. prior to the analysis. All analyses were performed immediately after sample thawing. Assay performance was verified by using the manufacturer-supplied controls.

\section{Serum PINP assay}

Serum PINP levels were determined by using IDS-[kit name] (Immunodiagnostic Systems) and iSYS analyser, according to the manufacturer's protocol. The two-site chemiluminometric assay involved a twopoint calibration in triplicate (the top calibrant value was approximately $135 \mathrm{mg} / \mathrm{l}$ ), quality control material (in duplicate), and $20 \mathrm{ml}$ of sample analysed in single. Specimens with PINP values above the assay range $(2-230 \mu \mathrm{g} / \mathrm{L})$ were diluted in specimens with low PINP levels. At each study centre, several analytical batches of specimens were analysed to establish reference intervals, by using the method during routine analyses of clinical samples. The stored specimens were analysed within 2 months of collection. Total PINP was measured electrochemiluminometrically using a Roche E170 automated analyser (Roche Diagnostics, Burgess Hill, UK, and Vivoord, Belgium). As described by the manufacturer and corroborated by published studies, the within- and between-calibration CVs of the assay were $<3.7 \%$ and $<2.9 \%$, respectively [7].

\section{Serum vitamin D assays}

Vitamin $\mathrm{D}$ active metabolites, 25-hydroxyvitamin $\mathrm{D}_{2}\left[25(\mathrm{OH}) \mathrm{D}_{2}\right]$ and 25-hydroxyvitamin $\mathrm{D}_{3}\left[25(\mathrm{OH}) \mathrm{D}_{3}\right]$, as a proportion of the total serum concentration of 25-hydroxyvitamin $\mathrm{D}[25(\mathrm{OH}) \mathrm{D}]$, were analysed using the commercially available Total $250 \mathrm{H}$ Vitamin D ELISA kits (BIOHIT OYJ, Helsinki, Finland), according to the manufacturer's protocol. All assays were performed in duplicate. In the current study, the intra-assay CV for $25(\mathrm{OH}) \mathrm{D}$ was below $4 \%$. Only samples that were not haemolysed were analysed.

\section{Statistical analysis}


Descriptive statistics were used to analyse mean \pm SD for all measured variables. The normality of distribution was checked using the Shapiro-Wilk's test. One-way analysis of variance (ANOVA) was used to determine the difference in WAnT performance characteristics (all variables) between the EG and PAM groups. In addition, the effect size of the analysed correlations was determined (Cohen's d-value). All calculations and graphics were generated using GraphPad Prism 6.0 (ftx.pl/program/graphpad-prism). Differences were considered statistically significant at $p \leq 0.05$.

\section{Results}

\section{Resting biochemical marker levels}

No differences in the resting values of analysed biochemical markers (vitamin D metabolites, PINP, and CTX) in the EG and PAM groups were observed even though the resting procalcitonin levels in the EG group were significantly higher than those in the PAM group (Table 2).

Table 2. Resting values of select biochemical markers in elite gymnast (EG) and physically active man (PAM)

\begin{tabular}{|c|c|c|c|c|c|c|}
\hline \multirow{2}{*}{ Variable } & \multirow{2}{*}{ Unit } & \multicolumn{2}{|c|}{$\mathrm{EG}(\mathrm{n}=16)$} & \multicolumn{2}{|c|}{ PAM $(\mathrm{n}=16)$} & \multirow{2}{*}{$\begin{array}{c}\text { Effect size } \\
\left(\eta^{2}\right)\end{array}$} \\
\cline { 3 - 6 } & & Mean $\pm \mathrm{SD}$ & $(95 \% \mathrm{CI})$ & Mean $\pm \mathrm{SD}$ & $(95 \% \mathrm{CI})$ & 0.08 \\
\hline $25(\mathrm{OH}) \mathrm{D}_{3}$ & $\mathrm{ng} / \mathrm{ml}$ & $\begin{array}{c}20.85 \pm \\
\end{array}$ & 3.93 & $\begin{array}{c}(18.57- \\
23.12)\end{array}$ & $\begin{array}{c}23.17 \pm \\
3.76\end{array}$ & $\begin{array}{c}(21.23- \\
25.10)\end{array}$ \\
\hline $24,25(\mathrm{OH})_{2} \mathrm{D}_{3}$ & $\mathrm{ng} / \mathrm{ml}$ & $1.38 \pm 0.66$ & $(1.00-1.77)$ & $1.67 \pm 0.84$ & $(1.24-2.11)$ & 0.03 \\
\hline $25(\mathrm{OH}) \mathrm{D}_{3} / 24,25(\mathrm{OH})_{2} \mathrm{D}_{3}$ & $\mathrm{ng} / \mathrm{ml}$ & $16.79 \pm$ & $(14.24-$ & $15.40 \pm$ & $(13.52-$ & 0.04 \\
& & 4.41 & $19.34)$ & 3.65 & $17.27)$ & \\
\hline Procalcitonin & $\mathrm{ng} / \mathrm{ml}$ & $0.44 \pm 0.17$ & $(0.34-0.54)$ & $0.27 \pm 0.15 *$ & $(0.19-0.34)$ & 0.23 \\
\hline C-terminal telopeptide of type I & $\mathrm{mg} / \mathrm{l}$ & $0.52 \pm 0.23$ & $(0.37-0.63)$ & $0.36 \pm 0.28$ & $(0.21-0.51)$ & 0.07 \\
collagen & & & & & & \\
\hline N-terminal propeptide of type I & $\mathrm{mg} / \mathrm{l}$ & $118.50 \pm$ & $(92.16-$ & $140.05 \pm$ & $(117.05-$ & 0.07 \\
collagen & & 43.15 & $144.83)$ & 41.45 & $163.04)$ & \\
\hline
\end{tabular}

*Significant difference between gymnasts and controls at $\mathrm{p}<0.01$

\section{Anaerobic performance}

The LBWT and UBWT data are presented in Fig. 1 and the results of ANOVA analysis are depicted in Table 3. The analysis of variance revealed a significant effect of gymnastic training (group factor) on the mean and peak power in UBWT. Regardless of $25(\mathrm{OH}) \mathrm{D}_{3}$ and $24,25(\mathrm{OH})_{2} \mathrm{D}_{3}$ levels, these values in EG group were $14.3 \%$ and $13.3 \%$ higher than those in the PAM group. In addition, the $25(\mathrm{OH}) \mathrm{D}_{3}$ and $24,25(\mathrm{OH})_{2} \mathrm{D}_{3}$ levels significantly affected the mean power in UBWT. The values were $8.8 \%$ higher in subjects with $25(\mathrm{OH}) \mathrm{D}_{3}$ levels over $22.50 \mathrm{ng} / \mathrm{ml}$ and in those with $24,25(\mathrm{OH})_{2} \mathrm{D}_{3}$ levels over $1.27 \mathrm{ng} / \mathrm{ml}$.

Table 3. Two-way (2 groups ' 2 concentrations) ANOVA analysis of the body mass-normalized performance in lower body Wingate test (LBWT) and upper body Wingate test (UBWT) 


\begin{tabular}{|c|c|c|c|c|c|c|}
\hline Variable & Effect & $\mathrm{df}$ & F & $\mathrm{p}$ & $\begin{array}{c}\text { Effect } \\
\text { size }\left(\eta^{2}\right) \\
\end{array}$ & Post-hoc outcome \\
\hline \multirow{5}{*}{$\begin{array}{c}\text { LBWT } \\
\text { mean power }\end{array}$} & $\mathrm{Gr}$ & 1,28 & 0.40 & 0.53 & 0.01 & \\
\hline & $\mathrm{D}_{3}$ Con & 1,28 & 0.20 & 0.65 & $<0.01$ & \\
\hline & $\mathrm{D}_{2}$ Con & 1,28 & 0.64 & 0.64 & 0.02 & \\
\hline & $\mathrm{Gr}^{\prime} \mathrm{D}_{3} \mathrm{Con}$ & 1,28 & 0.01 & 0.91 & $<0.01$ & \\
\hline & $\mathrm{Gr}{ }^{\prime} \mathrm{D}_{2} \mathrm{Con}$ & 1,28 & 0.05 & 0.82 & $<0.01$ & \\
\hline \multirow{5}{*}{$\begin{array}{c}\text { LBWT } \\
\text { peak power }\end{array}$} & $\mathrm{Gr}$ & 1,28 & 0.01 & 0.94 & $<0.01$ & \\
\hline & $\mathrm{D}_{3}$ Con & 1,28 & 1.30 & 0.26 & 0.04 & \\
\hline & $\mathrm{D}_{2}$ Con & 1,28 & 1.89 & 0.18 & 0.06 & \\
\hline & $\mathrm{Gr}^{\prime} \mathrm{D}_{3} \mathrm{Con}$ & 1,28 & 0.02 & 0.87 & $<0.01$ & \\
\hline & $\mathrm{Gr}^{\prime} \mathrm{D}_{2} \mathrm{Con}$ & 1,28 & 0.01 & 0.94 & $<0.01$ & \\
\hline \multirow{5}{*}{$\begin{array}{c}\text { UBWT } \\
\text { mean power }\end{array}$} & $\mathrm{Gr}$ & 1,28 & 13.62 & $0.01 * *$ & 0.34 & $\mathrm{EG}>\mathrm{PAM}$ \\
\hline & $\mathrm{D}_{3}$ Con & 1,28 & 5.63 & $0.02 *$ & 0.18 & $\mathrm{LD}_{3}<\mathrm{HD}_{3}$ \\
\hline & $\mathrm{D}_{2}$ Con & 1,28 & 5.70 & $0.02 *$ & 0.18 & $\mathrm{LD}_{24}<\mathrm{HD}_{24}$ \\
\hline & $\mathrm{Gr}{ }^{\prime} \mathrm{D}_{3} \mathrm{Con}$ & 1,28 & 0.94 & 0.33 & 0.03 & \\
\hline & $\mathrm{Gr}^{\prime} \mathrm{D}_{2} \mathrm{Con}$ & 1,28 & 0.93 & 0.34 & 0.03 & \\
\hline \multirow{5}{*}{$\begin{array}{c}\text { UBWT } \\
\text { peak power }\end{array}$} & $\mathrm{Gr}$ & 1,28 & 6.80 & $0.01 *$ & 0.20 & $\mathrm{EG}>\mathrm{PAM}$ \\
\hline & $\mathrm{D}_{3}$ Con & 1,28 & 2.72 & 0.11 & 0.09 & \\
\hline & $\mathrm{D}_{2}$ Con & 1,28 & 2.33 & 0.13 & 0.08 & \\
\hline & $\mathrm{Gr}^{\prime} \mathrm{D}_{3} \mathrm{Con}$ & 1,28 & 0.27 & 0.60 & 0.01 & \\
\hline & $\mathrm{Gr}{ }^{\prime} \mathrm{D}_{2} \mathrm{Con}$ & 1,28 & 0.42 & 0.53 & 0.01 & \\
\hline
\end{tabular}

Note: Gr, group; $\mathrm{D}_{3}$ Con, concentration of $25(\mathrm{OH}) \mathrm{D}_{3} ; \mathrm{D}_{2}$ Con, concentration of $24,25(\mathrm{OH})_{2} \mathrm{D}_{3}, \mathrm{LD}_{3}$, less than $22.50 \mathrm{ng} / \mathrm{ml} 25(\mathrm{OH}) \mathrm{D}_{3} ; \mathrm{HD}_{3}$, more than $22.50 \mathrm{ng} / \mathrm{ml} 25(\mathrm{OH}) \mathrm{D}_{3} ; \mathrm{LD}_{24}$, less than $1.27 \mathrm{ng} / \mathrm{ml} 24,25(\mathrm{OH})_{2} \mathrm{D}_{3} ; \mathrm{HD}_{24}$, more than $1.27 \mathrm{ng} / \mathrm{ml} 24,25(\mathrm{OH})_{2} \mathrm{D}_{3} ; \mathrm{EG}$, elite gymnast; PAM, physically active man.

Significant difference at $* \mathrm{p} \leq 0.05, * * \mathrm{p} \leq 0.01$

\section{Bone turnover marker levels after training}

Changes in the levels of bone turnover markers after LBWT and UBWT are presented in Fig. 2. The analysis of variance revealed a significant change in CTX levels 30 min post LBWT, and 5 and 30 min post UBWT (Table 4). At these time points, the CTX levels increased by $35.8 \%, 34.2 \%$, and $49.2 \%$, respectively, in the PAM group, but decreased by $10.9 \%, 7.0 \%$, and $5.8 \%$, respectively, in the EG group. Of note, the resting CTX values were significantly affected by $25(\mathrm{OH}) \mathrm{D}_{3}$ and $24,25(\mathrm{OH})_{2} \mathrm{D}_{3}$ levels. The resting CTX values were $50.2 \%$ higher in participants with $25(\mathrm{OH}) \mathrm{D}_{3}$ levels below $22.50 \mathrm{ng} / \mathrm{ml}$ and $39.5 \%$ higher in participants with $24,25(\mathrm{OH})_{2} \mathrm{D}_{3}$ below $1.27 \mathrm{ng} / \mathrm{ml}$. 
Analysis of PINP variance revealed a significant interaction of both factors only 30 min post LBWT. Further, post-hoc analysis indicated a 5.0\% decrease in resting PINP value 30 min post LBWT in EG participants with $25(\mathrm{OH}) \mathrm{D}_{3}$ levels over $22.50 \mathrm{ng} / \mathrm{ml}$; in PAM participants with $25(\mathrm{OH}) \mathrm{D}_{3}$ levels over 22.50 $\mathrm{ng} / \mathrm{ml}$, a $12.0 \%$ increase in resting PINP values was noted at that time point. A similar tendency was observed for participants with $24,25(\mathrm{OH})_{2} \mathrm{D}_{3}$ levels over $1.27 \mathrm{ng} / \mathrm{ml}$; however, it was not significant (Fig. 2B).

Table 4. Two-way (2 groups ' 2 concentrations) ANOVA analysis of the bone turnover marker responses induced by lower body Wingate testing (LBWT) and upper body Wingate testing (UBWT) 


\begin{tabular}{|c|c|c|c|c|c|c|}
\hline Variable & Effect & $\mathrm{df}$ & $\mathrm{F}$ & $\mathrm{p}$ & \begin{tabular}{|c|} 
Effect \\
size $\left(\eta^{2}\right)$
\end{tabular} & Post-hoc outcome \\
\hline \multirow{5}{*}{$\begin{array}{l}\text { CTX } \\
\text { rest }\end{array}$} & $\mathrm{Gr}$ & 1,28 & 2.41 & 0.13 & 0.07 & \multirow{5}{*}{$\begin{array}{l}\mathrm{LD}_{3}>\mathrm{HD}_{3} \\
\mathrm{LD}_{2}>\mathrm{HD}_{3}\end{array}$} \\
\hline & $\mathrm{D}_{3}$ Con & 1,28 & 12.81 & $0.01 * *$ & 0.31 & \\
\hline & $\mathrm{D}_{2}$ Con & 1,28 & 5.07 & $0.03 *$ & 0.18 & \\
\hline & $\mathrm{Gr}^{\prime} \mathrm{D}_{3} \mathrm{Con}$ & 1,28 & 0.02 & 0.87 & $<0.01$ & \\
\hline & $\mathrm{Gr}^{\prime} \mathrm{D}_{2} \mathrm{Con}$ & 1,28 & 0.27 & 0.60 & 0.01 & \\
\hline \multirow{5}{*}{$\begin{array}{c}\text { CTX } \\
\text { change } 5 \text { min post } \\
\text { LBWT }\end{array}$} & $\mathrm{Gr}$ & 1,28 & 2.78 & 0.10 & 0.09 & \\
\hline & $\mathrm{D}_{3}$ Con & 1,28 & 2.16 & 0.15 & 0.07 & \\
\hline & $\mathrm{D}_{2}$ Con & 1,28 & 2.35 & 0.13 & 0.09 & \\
\hline & $\mathrm{Gr}{ }^{\prime} \mathrm{D}_{3} \mathrm{Con}$ & 1,28 & 0.93 & 0.34 & 0.03 & \\
\hline & $\mathrm{Gr}^{\prime} \mathrm{D}_{2} \mathrm{Con}$ & 1,28 & 1.32 & 0.26 & 0.04 & \\
\hline \multirow{5}{*}{$\begin{array}{c}\text { CTX } \\
\text { change } 30 \text { min post } \\
\text { LBWT }\end{array}$} & $\mathrm{Gr}$ & 1,28 & 8.55 & $0.01 * *$ & 0.24 & \multirow[t]{5}{*}{$\mathrm{EG}<\mathrm{PAM}$} \\
\hline & $\mathrm{D}_{3} \mathrm{Con}$ & 1,28 & 1.67 & 0.20 & 0.05 & \\
\hline & $\mathrm{D}_{2}$ Con & 1,28 & 3.04 & 0.09 & 0.11 & \\
\hline & $\mathrm{Gr}^{\prime} \mathrm{D}_{3} \mathrm{Con}$ & 1,28 & 1.03 & 0.31 & 0.03 & \\
\hline & $\mathrm{Gr}^{\prime} \mathrm{D}_{2} \mathrm{Con}$ & 1,28 & 2.17 & 0.15 & 0.07 & \\
\hline \multirow{5}{*}{$\begin{array}{c}\text { CTX } \\
\text { change } 5 \text { min post } \\
\text { UBWT }\end{array}$} & $\mathrm{Gr}$ & 1,28 & 5.70 & $0.02 *$ & 0.18 & \multirow[t]{5}{*}{$\mathrm{EG}<\mathrm{PAM}$} \\
\hline & $\mathrm{D}_{3}$ Con & 1,28 & 1.25 & 0.27 & 0,04 & \\
\hline & $\mathrm{D}_{2}$ Con & 1,28 & 2.72 & 0.11 & 0.09 & \\
\hline & $\mathrm{Gr}^{\prime} \mathrm{D}_{3} \mathrm{Con}$ & 1,28 & 0.38 & 0.54 & $<0,01$ & \\
\hline & $\mathrm{Gr}^{\prime} \mathrm{D}_{2} \mathrm{Con}$ & 1,28 & 1.27 & 0.26 & 0.04 & \\
\hline \multirow{5}{*}{$\begin{array}{c}\text { CTX } \\
\text { change } 30 \text { min post } \\
\text { UBWT }\end{array}$} & $\mathrm{Gr}$ & 1,28 & 6.01 & $0.02 *$ & 0.19 & \multirow{5}{*}{$\mathrm{EG}<\mathrm{PAM}$} \\
\hline & $\mathrm{D}_{3}$ Con & 1,28 & 1.12 & 0.29 & 0.04 & \\
\hline & $\mathrm{D}_{2}$ Con & 1,28 & 2.04 & 0.16 & 0.07 & \\
\hline & $\mathrm{Gr}^{\prime} \mathrm{D}_{3} \mathrm{Con}$ & 1,28 & 0.01 & 0.94 & $<0.01$ & \\
\hline & $\mathrm{Gr}^{\prime} \mathrm{D}_{2} \mathrm{Con}$ & 1,28 & 0.17 & 0.68 & $<0.01$ & \\
\hline \multirow{5}{*}{$\begin{array}{r}\text { PINP } \\
\text { rest }\end{array}$} & $\mathrm{Gr}$ & 1,28 & 1.85 & 0,22 & 0.07 & \\
\hline & $\mathrm{D}_{3}$ Con & 1,28 & 0.17 & 0.67 & $<0.01$ & \\
\hline & $\mathrm{D}_{2}$ Con & 1,28 & 0.22 & 0.63 & $<0.01$ & \\
\hline & $\mathrm{Gr}^{\prime} \mathrm{D}_{3} \mathrm{Con}$ & 1,28 & 1.77 & 0.19 & 0.06 & \\
\hline & $\mathrm{Gr}^{\prime} \mathrm{D}_{2} \mathrm{Con}$ & 1,28 & 0.33 & 0.56 & 0.01 & \\
\hline \multirow{5}{*}{$\begin{array}{c}\text { PINP } \\
\text { change } 5 \text { min post } \\
\text { LBWT }\end{array}$} & \multirow{5}{*}{$\begin{array}{c}\mathrm{Gr} \\
\mathrm{D}_{3} \text { Con } \\
\mathrm{D}_{2} \text { Con }\end{array}$} & 1,28 & 0.84 & 0.40 & 0.02 & \\
\hline & & 1,28 & 0.30 & 0.58 & 0.01 & \\
\hline & & 1,28 & 0.37 & 0.54 & 0.01 & \\
\hline & & 1,28 & 2.20 & 0.15 & 0.09 & \\
\hline & & 1,28 & 2.76 & 0.11 & 0.10 & \\
\hline
\end{tabular}




\begin{tabular}{|c|c|c|c|c|c|c|}
\hline & $\left|\begin{array}{l}G r{ }^{\prime} D_{3} \text { Con } \\
G r D_{2} \text { Con }\end{array}\right|$ & & & & & \\
\hline PINP & $\mathrm{Gr}$ & 1,28 & 0,95 & 0.37 & 0.03 & \multirow{5}{*}{ EG-HD $3<{\mathrm{PAM}-\mathrm{HD}_{3}}$} \\
\hline change 30 min post & $\mathrm{D}_{3} \mathrm{Con}$ & 1,28 & 0.58 & 0.45 & 0.02 & \\
\hline \multirow[t]{3}{*}{ LBWT } & $\mathrm{D}_{2}$ Con & 1,28 & 0.24 & 0.62 & 0.02 & \\
\hline & $\mathrm{Gr}^{\prime} \mathrm{D}_{3} \mathrm{Con}$ & 1,28 & 4.90 & 0.03* & 0.18 & \\
\hline & $\mathrm{Gr}^{\prime} \mathrm{D}_{2} \mathrm{Con}$ & 1,28 & 3.82 & 0.06 & 0.19 & \\
\hline PINP & $\mathrm{Gr}$ & 1,28 & 0.05 & 0.82 & $<0.01$ & \\
\hline change 5 min post & $\mathrm{D}_{3}$ Con & 1,28 & 1.09 & 0.31 & 0.04 & \\
\hline \multirow[t]{3}{*}{ UBWT } & $\mathrm{D}_{2}$ Con & 1,28 & 0.98 & 0.33 & 0.04 & \\
\hline & $\mathrm{Gr}^{\prime} \mathrm{D}_{3} \mathrm{Con}$ & 1,28 & 1.82 & 0.19 & 0.07 & \\
\hline & $\mathrm{Gr}^{\prime} \mathrm{D}_{2} \mathrm{Con}$ & 1,28 & 1.98 & 0.17 & 0.09 & \\
\hline PINP & $\mathrm{Gr}$ & 1,28 & 0.13 & 0.72 & $<0.01$ & \\
\hline \multirow[t]{4}{*}{ change 30 min post UBWT } & $\mathrm{D}_{3}$ Con & 1,28 & 1.39 & 0.25 & 0.06 & \\
\hline & $\mathrm{D}_{2}$ Con & 1,28 & 1.29 & 0.26 & 0.05 & \\
\hline & $\mathrm{Gr}^{\prime} \mathrm{D}_{3} \mathrm{Con}$ & 1,28 & 0.78 & 0.38 & 0.03 & \\
\hline & $\mathrm{Gr}^{\prime} \mathrm{D}_{2} \mathrm{Con}$ & 1,28 & 1.10 & 0.30 & 0.04 & \\
\hline
\end{tabular}

Note: CTX, C-terminal telopeptide of type I collagen; PINP, N-terminal propeptide of type I collagen; Gr, group; $\mathrm{D}_{3}$ Con, concentration of $25(\mathrm{OH}) \mathrm{D}_{2} ; \mathrm{D}_{2}$ Con, concentration of $24,25(\mathrm{OH}) 2 \mathrm{D}_{3} ; \mathrm{LD}_{3}, 25(\mathrm{OH}) \mathrm{D}_{3}$ levels below 22.50 $\mathrm{ng} / \mathrm{ml} ; \mathrm{HD}_{3}, 25(\mathrm{OH}) \mathrm{D}_{3}$ levels above $22.50 \mathrm{ng} / \mathrm{ml} ; \mathrm{LD}_{2}, 24,25(\mathrm{OH})_{2} \mathrm{D}_{3}$ levels below $1.27 \mathrm{ng} / \mathrm{ml} \mathrm{HD}$, $24,25(\mathrm{OH})_{2} \mathrm{D}_{3}$ levels above $1.27 \mathrm{ng} / \mathrm{ml}$; EG, elite gymnast; PAM, physically active man.

Significant difference at $* \mathrm{p} \leq 0.05, * * \mathrm{p} \leq 0.01$

\section{Discussion}

In the present study, we demonstrated that WAnT induced a significantly different response in the levels of the bone resorption marker CTX in the EG and PAM groups. While CTX levels after WAnT did not change in the EG group, they significantly increased in the PAM group. This indicates that specialist gymnastic training induces adaptive changes that protect the skeletal muscle from a resorption state induced by acute exercise. Consistently, gymnasts have higher bone mineral density than runners or swimmers [18]. The effect of exercise on markers of bone formation and resorption has been evaluated in several studies; however, the findings are inconsistent [1, [12, [19]. Factors that modulate exerciseinduced changes in bone marker levels remain to be identified. 
Here, we observed that the mean and peak power reached in WAnT for the arm was significantly higher in the EG group than in the PAM group. Conversely, no difference in WAnT leg performance was noted between the groups. These observations indicate that the leg power output was the same in both groups. However, the arm power output was higher in the EG group. Bearing in mind that both WAnT tests significantly increased the CTX levels only in the PAM group, it cannot be assumed that the power output, local muscle strength, or anaerobic metabolism activity are responsible for these differences.

\section{Response to WAnT and vitamin D}

To determine whether the vitamin $\mathrm{D}$ status determines the effect of exercise on bone turnover marker levels, we measured the serum $25(\mathrm{OH}) \mathrm{D}$ and $24,25(\mathrm{OH})_{2} \mathrm{D}$ levels. Vitamin $\mathrm{D}$ greatly impacts bone metabolism; however, only limited data are available on the effect of exercise in relation to vitamin $D$ status on bone formation and resorption markers. For instance, in professional soccer players, the resting values of bone markers were unchanged after a summer season even though a significant increase in 25(OH)D levels was observed [20]. In addition, the reports on the effect of vitamin D supplementation on marker levels are conflicting. For example, in one study involving Chines adults, vitamin D supplementation increased serum levels of bone alkaline phosphatase, but did not affect PINP and CTX levels. However, in subjects whose 25(OH)D concentration exceeded $30 \mathrm{ng} / \mathrm{ml}$, an increase of CTX levels was observed [21]. Conversely, it has been demonstrated that improved vitamin D status in younger postmenopausal women leads to a significant reduction in serum CTX and PINP levels [22]. The findings of the current study are in agreement with the latter study, in that we observed that in both EG and PAM groups, concentration of 25(OH)D below the median value of $22.50 \mathrm{ng} / \mathrm{ml}$ was associated with higher CTX levels at baseline. Conversely, 30 min post LBWT, the increase in PINP levels was higher in the PAM group than in the EG group, but only in participants with $25(\mathrm{OH}) \mathrm{D}_{3}$ levels over $22.50 \mathrm{ng} / \mathrm{ml}$.

It is important to note that both osteoclast and osteoblast express CYP27B1, an enzyme that converts $25(\mathrm{OH}) \mathrm{D}$ to $1,25(\mathrm{OH})_{2} \mathrm{D}_{3}$ [23]. Metabolism of $25(\mathrm{OH}) \mathrm{D}$ results in the formation of $1,25(\mathrm{OH})_{2} \mathrm{D}_{3}$, which is a critical bioactive form of vitamin D. Hence, appropriate blood levels of 25(OH)D should guarantee sufficient synthesis of $1,25(\mathrm{OH})_{2} \mathrm{D}_{3}$ by the bone cell, which can exert auto- and paracrine functions. Interestingly, concentration of the inactive form of vitamin $D, 24,25(\mathrm{OH})_{2} \mathrm{D}_{3}$, below the median value of $1.27 \mathrm{ng} / \mathrm{ml}$ was also associated with higher CTX values at baseline. Another metabolic pathway, catalysed by CYP24A1, leads to formation of $24,25(\mathrm{OH})_{2} \mathrm{D}_{3}$, which has been consider to be inactive metabolite of vitamin D. However, studies of recent years indicate that it can have several biological functions. For example it can reduces the toxic effects of $1,25(\mathrm{OH})_{2} \mathrm{D}_{3}$ and is an important regulator of bone healing of fracture [24]. Besides, in individuals with renal insufficiency, treatment with $1,25(\mathrm{OH})_{2} \mathrm{D}_{3}$ leads to hypercalcemia, but this effect is reversed when the individuals are additionally treated with $24,25(\mathrm{OH})_{2} \mathrm{D}_{3}$ [25]. Our data indicates that $24,25(\mathrm{OH})_{2} \mathrm{D}_{3}$ can be an important factor regulating endocrine function of bone cells. 
Collectively, the data from the current study indicate that vitamin D modulates the changes in bone remodeling marker levels in trained and untrained subjects. Further, the degree of adaptation to a specific sport and vitamin D status both impact the effect of exercise on bone metabolism markers.

\section{Strengths and limitations of the study}

One limitation of the current study is that we only measured two metabolites of vitamin D. According to an increasing number of studies, $1,25(\mathrm{OH})_{2} \mathrm{D}_{3}$ as well as $24,25(\mathrm{OH})_{2} \mathrm{D}_{3}, 3$-epi-25(OH)D, and possibly other vitamin $\mathrm{D}$ metabolites play an important role in bone and calcium metabolism [24, [26, [27].

Consequently, one can expect that they also modulate the effects of exercise on bone formation and resorption. In addition, exercise by itself can modify vitamin $D$ metabolism. For example, 30 min of cycling significantly increases serum $25(\mathrm{OH}) \mathrm{D}_{3}$ levels [19], beside endurance exercise has been shown to increase serum concentration of $24,25(\mathrm{OH})_{2} \mathrm{D}_{3}, 3-\mathrm{epi}-25(\mathrm{OH}) \mathrm{D}$ [28]. Further, the effect of exercise on the osteoblast and osteoclast metabolism, in addition to the direct effect of loading, is also modified by myokines, such as IL-6, IGF-1, FGF2, and others [29, [30]. Therefore, we cannot exclude the possibility that the observed modulatory effect of vitamin $\mathrm{D}$ on bone formation and resorption markers is also mediated by myokines.

\section{Declarations}

Funding (The study was funded by Knowledge Grant of Polish Ministry of Science and Higher Education number NRSA 406754).

Conflicts of interest/Competing interests (Jan Mieszkowski, Andrzej Kochanowicz, Elżbieta Piskorska, Bartłomiej Niespodziński, Joanna Siódmiak, Krzysztof Buśko, Dorota Olszewska-Słonina, Jędrzej Antosiewicz declare that they have no conflict of interest. The results of this study are presented clearly, honestly, and without fabrication, falsification, or inappropriate data manipulation)

Ethics approval (Experimental procedures and study design were approved by the Bioethics Committee for Clinical Research at the Regional Medical Chamber in Gdańsk, Poland. The study was conducted according to the 1964 Declaration of Helsinki and its later amendments)

Consent to participate (Each participant gave a written consent to participate in the study, and was informed about the purpose and test procedures, and the possibility of withdrawal of consent at any time and for any reason.)

Consent for publication (Consent to submit has been received from all co-authors)

Availability of data and material (All individual deidentified participant data are available for the next 5 years on reasonable request from the first author)

Code availability (not applicable) 
Authors' contributions (as attached)

\section{Ethical approval}

All procedures performed in studies involving human participants were in accordance with the ethical standards of the institutional and/or national research committee and with the 1964 Declaration of Helsinki and its later amendments or comparable ethical standards.

\section{Informed consent}

Informed consent was obtained from all individual participants included in the study.

\section{References}

1. Gombos GC, Bajsz V, Pek E, Schmidt B, Sio E, Molics B, and Betlehem J. Direct effects of physical training on markers of bone metabolism and serum sclerostin concentrations in older adults with low bone mass. BMC Musculoskelet Disord. 2016;17:254.

2. Maimoun L and Sultan C. Effects of physical activity on bone remodeling. Metabolism. 2011;60:37388.

3. Leeming DJ, Henriksen K, Byrjalsen I, Qvist P, Madsen SH, Garnero P, and Karsdal MA. Is bone quality associated with collagen age? Osteoporos Int. 2009;20:1461-70.

4. Maimoun $L$ and Sultan $C$. Effect of physical activity on calcium homeostasis and calciotropic hormones: A review. Calcif Tissue Int. 2009;85:277-86.

5. Frost HM. Skeletal structural adaptations to mechanical usage (satmu): 1. Redefining wolff's law: The bone modeling problem. Anat Rec. 1990;226:403-13.

6. Banfi G, Lombardi G, Colombini A, and Lippi G. Bone metabolism markers in sports medicine. Sports Med. 2010;40:697-714.

7. Seibel MJ. Biochemical markers of bone turnover: Part i: Biochemistry and variability. Clin Biochem Rev. 2005;26:97-122.

8. Garnero P. The utility of biomarkers in osteoporosis management. Mol Diagn Ther. 2017;21:401-418.

9. Karabulut M, Bemben DA, Sherk VD, Anderson MA, Abe T, and Bemben MG. Effects of high-intensity resistance training and low-intensity resistance training with vascular restriction on bone markers in older men. Eur J Appl Physiol. 2011;111:1659-67.

10. Pirila S, Taskinen M, Turanlahti M, Kajosaari M, Makitie O, Saarinen-Pihkala UM, and Viljakainen H. Bone health and risk factors of cardiovascular disease - a cross-sectional study in healthy young adults. Plos One. 2014;9.

11. Leli C, Pasqualini L, Vaudo G, Gaggioli S, Scarponi AM, and Mannarino E. Carotid intima-media thickness and bone turnover: The role of c-terminal telopeptide of type i collagen. Internal and Emergency Medicine. 2010;5:127-134. 
12. Haakonssen EC, Ross ML, Knight EJ, Cato LE, Nana A, Wluka AE, Cicuttini FM, Wang BH, Jenkins DG, and Burke LM. The effects of a calcium-rich pre-exercise meal on biomarkers of calcium homeostasis in competitive female cyclists: A randomised crossover trial. PLoS One. 2015;10:e0123302.

13. Kujach S, Lyzwinski D, Chroboczek M, Bialowas D, Antosiewicz J, and Laskowski R. The effect of vitamin d-3 supplementation on physical capacity among active college-aged males. Nutrients. 2020;12.

14. Dzik KP, Skrobot W, Kaczor KB, Flis DJ, Karnia MJ, Libionka W, Antosiewicz J, Kloc W, and Kaczor JJ. Vitamin d deficiency is associated with muscle atrophy and reduced mitochondrial function in patients with chronic low back pain. Oxid Med Cell Longev. 2019;2019:6835341.

15. Dzik KP and Kaczor JJ. Mechanisms of vitamin d on skeletal muscle function: Oxidative stress, energy metabolism and anabolic state. Eur J Appl Physiol. 2019;119:825-839.

16. Mukhopadhyay P, Ghosh S, Bhattacharjee K, and Chowdhury S. Inverse relationship between 25 hydroxy vitamin d and parathormone: Are there two inflection points? Indian J Endocrinol Metab. 2019;23:422-427.

17. Bar-Or 0 . The wingate anaerobic test. An update on methodology, reliability and validity. Sports Med. 1987;4:381-94.

18. Taaffe DR, Robinson TL, Snow CM, and Marcus R. High-impact exercise promotes bone gain in welltrained female athletes. J Bone Miner Res. 1997;12:255-60.

19. Sun X, Cao ZB, Taniguchi H, Tanisawa K, and Higuchi M. Effect of an acute bout of endurance exercise on serum 25(oh)d concentrations in young adults. J Clin Endocrinol Metab. 2017;102:39373944.

20. Kopec A, Solarz K, Majda F, Slowinska-Lisowska M, and Medras M. An evaluation of the levels of vitamin $\mathrm{d}$ and bone turnover markers after the summer and winter periods in polish professional soccer players. J Hum Kinet. 2013;38:135-40.

21. Yao P, Sun L, Xiong Q, Xu X, Li H, and Lin X. Cholecalciferol supplementation promotes bone turnover in chinese adults with vitamin d deficiency. J Nutr. 2018;148:746-751.

22. Nahas-Neto J, Cangussu LM, Orsatti CL, Bueloni-Dias FN, Poloni PF, Schmitt EB, and Nahas EAP. Effect of isolated vitamin d supplementation on bone turnover markers in younger postmenopausal women: A randomized, double-blind, placebo-controlled trial. Osteoporos Int. 2018;29:1125-1133.

23. van Driel M, Koedam M, Buurman CJ, Hewison M, Chiba H, Uitterlinden AG, Pols HA, and van Leeuwen JP. Evidence for auto/paracrine actions of vitamin d in bone: 1alpha-hydroxylase expression and activity in human bone cells. FASEB J. 2006;20:2417-9.

24. Seo EG, Einhorn TA, and Norman AW. 24r,25-dihydroxyvitamin d3: An essential vitamin d3 metabolite for both normal bone integrity and healing of tibial fracture in chicks. Endocrinology. 1997;138:386472.

25. Birkenhager-Frenkel DH, Pols HA, Zeelenberg J, Eijgelsheim JJ, Schot R, Nigg AL, Weimar W, Mulder PG, and Birkenhager JC. Effects of 24r,25-dihydroxyvitamin d3 in combination with 1 alpha- 
hydroxyvitamin d3 in predialysis renal insufficiency: Biochemistry and histomorphometry of cancellous bone. J Bone Miner Res. 1995;10:197-204.

26. Brown AJ, Ritter CS, Weiskopf AS, Vouros P, Sasso GJ, Uskokovic MR, Wang G, and Reddy GS. Isolation and identification of 1alpha-hydroxy-3-epi-vitamin d3, a potent suppressor of parathyroid hormone secretion. J Cell Biochem. 2005;96:569-78.

27. Seo EG and Norman AW. Three-fold induction of renal 25-hydroxyvitamin d3-24-hydroxylase activity and increased serum 24,25-dihydroxyvitamin d3 levels are correlated with the healing process after chick tibial fracture. J Bone Miner Res. 1997;12:598-606.

28. Mieszkowski J, Stankiewicz B, Kochanowicz A, Niespodziński B, Kowalik T, Żmijewski M, Kowalski K, Rola R, Bieńkowski T, and Antosiewicz J. Ultra-marathon-induced increase in serum levels of vitamin d metabolites: A double-blind randomized controlled trial. Nutrients . 2020;12.

29. Zhang J, Valverde P, Zhu X, Murray D, Wu Y, Yu L, Jiang H, Dard MM, Huang J, Xu Z, Tu Q, and Chen $J$. Exercise-induced irisin in bone and systemic irisin administration reveal new regulatory mechanisms of bone metabolism. Bone Res. 2017;5:16056.

30. Tagliaferri C, Wittrant $\mathrm{Y}$, Davicco MJ, Walrand S, and Coxam V. Muscle and bone, two interconnected tissues. Ageing Res Rev. 2015;21:55-70.

\section{Figures}



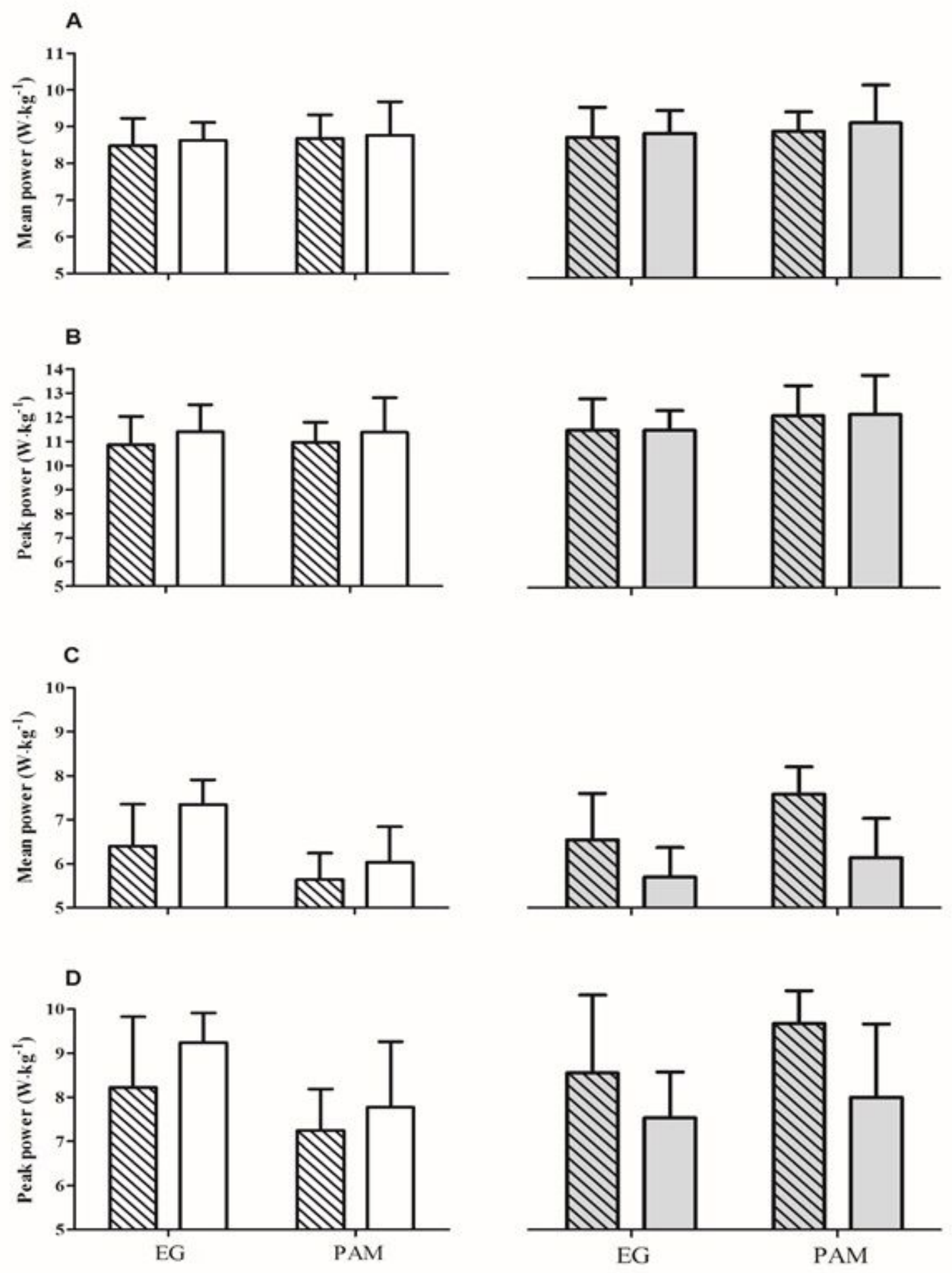

\section{Figure 1}

The relative mean and peak power of anaerobic exercise in elite gymnast (EG) and physically active man (PAM) depending on vitamin D3 levels. White bars with stripes, 25(OH)D3 levels below $22.50 \mathrm{ng} / \mathrm{ml}$; white bars, 25(OH)D3 levels above $22.50 \mathrm{ng} / \mathrm{ml}$; grey bars with stripes, 24,25(OH)2D3 levels below $1.27 \mathrm{ng} / \mathrm{ml}$; grey bars, 24,25(OH)2D3 levels above $1.27 \mathrm{ng} / \mathrm{ml}$; LBT, lower body test; UBT, upper body test 

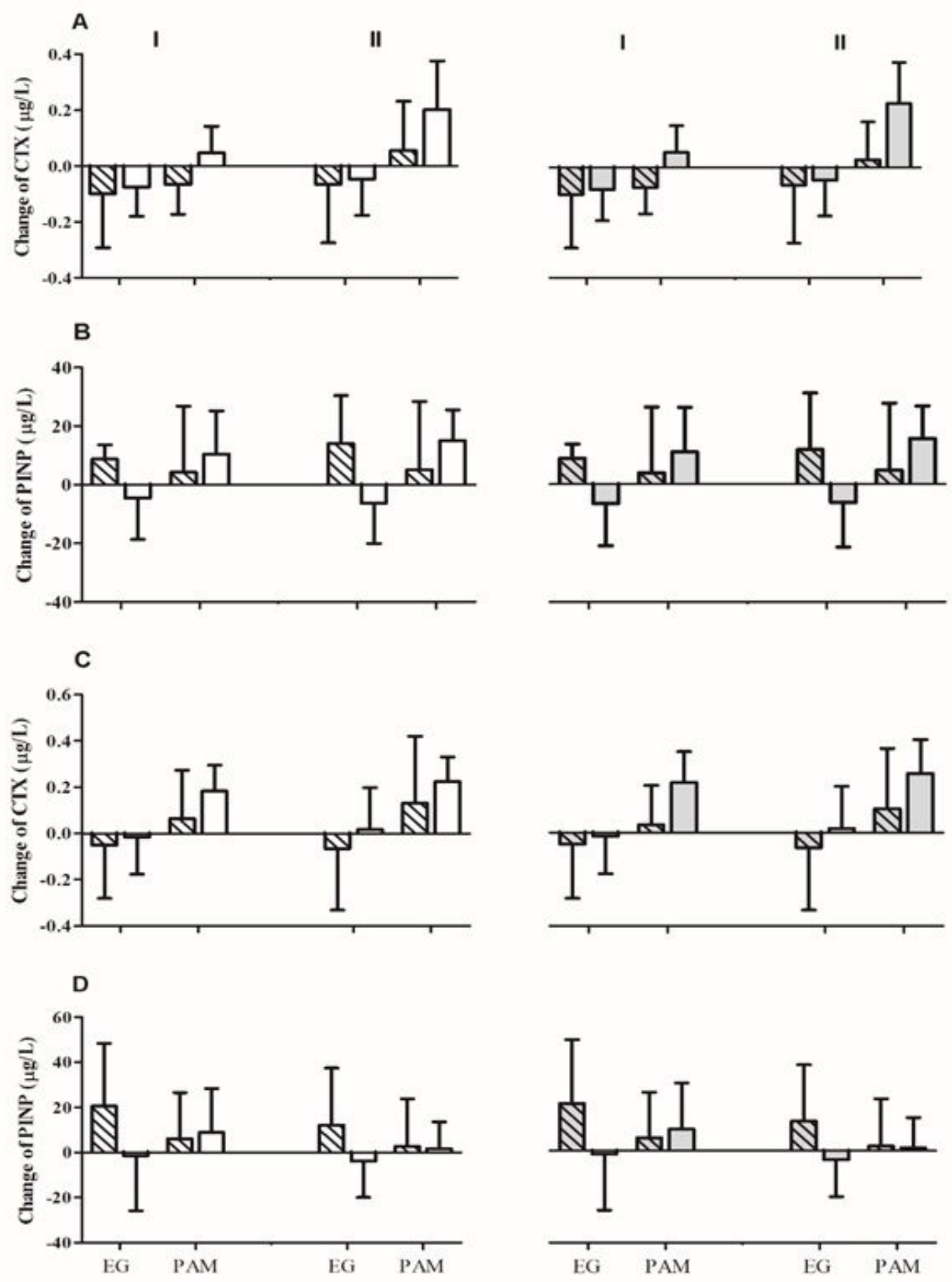

Figure 2

Changes in the bone turnover marker levels after Wingate anaerobic test (WAnT) in elite gymnast (EG) and physically active man (PAM) depending on the vitamin D3 levels. CTX, C-terminal telopeptide of type I collagen; PINP, N-terminal propeptide of type I collagen; A and B, lower body Wingate testing; C and D, upper body Wingate testing; I, changes in the peripheral blood 5 min post WAnT; II, changes in the peripheral blood 30 min post WAnT; white bars with stripes, 25(OH)D3 levels below $22.50 \mathrm{ng} / \mathrm{ml}$; white 
bars, 25(OH)D3 levels above $22.50 \mathrm{ng} / \mathrm{ml}$; grey bars with stripes, 24,25(OH)2D3 levels below $1.27 \mathrm{ng} / \mathrm{ml}$; grey bars, 24,25(OH)2D3 levels above $1.27 \mathrm{ng} / \mathrm{ml}$ 